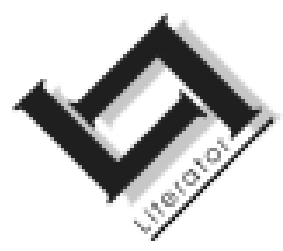

\title{
Waardepeilings van die digkuns van C.M. van den Heever
}

\author{
Bernard Odendaal \\ Departement Afrikaans en Nederlands, Duits en Frans \\ Universiteit van die Vrystaat \\ BLOEMFONTEIN \\ E-pos: odenbj@hum.uovs.ac.za
}

\section{Abstract \\ Evaluations of the poetry of C.M. van den Heever}

This article traces the assessments of the value of the poetic work by the Afrikaans author C.M. van den Heever since the second quarter of the twentieth century. Appreciation of him as poet mainly revolves around his role as transitional figure in the important renewal of Afrikaans poetry in the 1930s, as can be seen from two rather divergent critiques by D.J. Opperman (completed in 1946 and 1952, respectively). An outstanding contribution by Van den Heever in this regard is the introduction of elements of Dutch poetry from around the turn of the nineteenth century to the Afrikaans literary world. A critic such as T.T. Cloete, in an article dating from 1957, convincingly argues that aspects of Van den Heever's poetic style and technique, which other critics had sometimes judged harshly, are largely functional in co-communicating the specific (passively transcendental) attitude towards life and reality conveyed in Van den Heever's work. Local and international shifts in the dominant literary approaches, however, have caused singularly confessional poetry - such as the bulk of Van den Heever's poetic output - to be increasingly marginalised since the mid1930s. In this respect he shares the fate of Dutch poet A. Roland Holst, whose poetry was influential in shaping the characteristics of Van den Heever's.

\section{Opsomming}

Waardepeilings van die digkuns van C.M. van den Heever

In dié artikel word die waardepeilings van C.M. van den Heever se poësie sedert die tweede kwart van die twintigste eeu nagespeur. Waardering vir sy digterskap berus hoofsaaklik op sy rol as oorgangsfiguur in die belangrike vernuwing van Dertig in die Afrikaanse poësie, soos blyk uit die nogal uiteenlopende twee resepsies deur D.J. Opperman (onderskeidelik 
voltooi in 1946 en 1952). 'n Uitmuntende bydrae deur Van den Heever in hierdie verband is sy bekendstelling van Nederlandse literêre strominge van rondom die wending van die negentiende eeu in die Afrikaanse letterkunde. Die kritikus T.T. Cloete het in 'n artikel uit 1957 oortuigend geargumenteer dat aspekte van Van den Heever se digstyl en -tegniek, wat soms onder ernstige kritiek moes deurloop, grootliks funksioneel is om die bepaalde (passief-transendentale) lewens- en werklikheidsingesteldheid in sy werk te ko-kommunikeer. Plaaslike en internasionale verskuiwings in heersende literatuuropvattings het egter tot gevolg gehad dat eensydig belydende poësie, soos dié van Van den Heever, toenemend gemarginaliseer geraak het sedert 1930. In hierdie opsig deel hy die lot van die Nederlandse digter A. Roland Holst, wie se digkuns 'n belangrike rol gespeel het in die vorming van die aard van Van den Heever s'n.

\section{Vroeë waardering vir Van den Heever se digterskap}

C.M. van den Heever se prosateurskap word vandag veel belangriker geag as sy digterskap (Du Plooy, 1999:658; Kannemeyer, 1998:34). Vernaamlik as plaasromanskrywer neem hy 'n kernposisie in ons letterkunde in (Du Plooy, 1999:658; Van Coller, 1987; Coetzee, 2000).

Dit was egter nie altyd die geval dat die voorkeur by sy prosawerk gelê het nie. Hoewel Elisabeth Eybers in 'n 1938-resensie van Aardse vlam reeds reken dat sy aansien as digter op daardie stadium "'n ietwat misleidende afglans van sy algemene bekendheid as romanskrywer, kultuurleier en geleerde" was (Eybers, 1978:37), was 'n prominente literatuurhistorikus soos Gerrit Dekker (1959:22) en iemand soos die skerpsinnige digter en kritikus Ernst van Heerden (1971:56) in die tyd net ná Van den Heever se dood in 1957 nog van mening dat hy veral as digter 'n belangrike plek in die Afrikaanse literatuur sou behou.

Die waardering vir hom as digter berus in die eerste plek op sy rol as oorgangsfiguur tot Dertig (vgl. onder meer Opperman; s.j.:131; Antonissen, s.j.:220; Dekker, s.j.:188; Kannemeyer, 1998:27, 34; en Ohlhoff, 1999:73) en/of as "eerste Dertiger" (vgl. Opperman, s.j.:137; Antonissen, s.j.:225; Dekker, s.j.188; en Ohlhoff, 1999:73). Laasgenoemde posisie het Van den Heever volgens Ernst van Heerden (1971:51) met Aardse vlam, die hoogtepunt van Van den Heever se poësie-oeuvre, probeer bestendig: "Dit was 'n manmoedige poging om die hoof te bied aan die voortreflike digkuns van die 'jong' Dertigers, by name Van Wyk Louw, en om bewys te lewer dat sy eie funksie in die 'vernuwing' méér as dié van 'n 'voorloper' was." 


\section{Twee verskillende beoordelings deur D.J. Opperman}

D.J. Opperman se twee langerige stukke oor Van den Heever as digter bied ' $n$ interessante blik op die waardering vir hom in hierdie verband. In 'n opstel oor die "vroulike" en "manlike" in die poësie van veral C.M. van den Heever, geskryf in 1946 en gepubliseer in die opstelbundel Wiggelstok (Opperman, 1959:40-53), plaas hy Van den Heever in 'n lyn van wat hy beskryf as "vroulik" en "Oosters" ingestelde Afrikaanse digters. Hierdie tradisie stel Opperman teenoor 'n "manlike" en "Westerse" Iyn. Met "vroulik" en "Oosters" verbind hy kenmerke en motiewe soos droom, stemming, passiwiteit, weemoed, verlange, swaarmoedigheid, werklikheidsafgekeerdheid, onmaatskaplikheid, verganklikheidsbewustheid en doodsverlange, terwyl "manlik" en "Westers" syns insiens onder meer geassosieer word met die dadedrang, werklikheidsin, heldedom en leierskap, rasionaliteit, forsheid en aardsheid.

Hy toon aan dat vroulike simbole in Van den Heever se poësie oorheers: water, skemering, mantel, maan, musiek, koningin, bruid, lelie, grotte, beker, skulp, kelk en vaas. Dit impliseer byvoorbeeld 'n begeerte na voorgeboortelike rus en beskerming, 'n verlange na wedergeboorte. Ook druk die voorkeur vir byvoorbeeld die voorsetsel "deur" - in frases soos (die digter) "deur wie oneindighede gaan" en "(ek) voel deur my U groter lewe gaan" - 'n vroulike "verlange" en "reseptiwiteit" uit. Hy skryf voorts dat die estetiese aard van Van den Heever se gedigte tastend en amorf is - "ameboïed" - deur die vloeibeweging van die stromende volsinne en enjambemente, deur die swewende ritme en die eenselwige woordgebruik.

Die aard van die ontroering in Van den Heever se verse bestempel Opperman as ontgrensend - soos 'n "lens ... uit fokus". Daar heers 'n "vae onbestemde gevoel", veral 'n onbepaalde somberheid. Hy bemerk 'n bepaalde vormloosheid in die willekeurige (en dikwels "vergeestelikende") woordverbindings waarvoor Van den Heever lief is (byvoorbeeld "lewensmurasies", "skoonheidstuin" en "herinneringsmantel"); ook in die uitroepe en antiklimakse, die spanningslose enjambemente, die swak ryme. Die baie invloede wat in Van den Heever se gedigte uitstroom, verskerp volgens hom die indruk van 'n sekere wesenloosheid.

In die waardebepalende slot van die opstel (Opperman, 1959:53) plaas hy Van den Heever hiërargies laaste in die vroulik-Oosterse lyn, wat ook Totius, W.E.G. Louw en Elisabeth Eybers insluit. Van den Heever se vers het "die minste klaarheid", is die "beperkste", meen hy. En hoewel hy stel dat hy die vroulik-Oosterse poësie nie prinsipieel geringer skat as die manlik-Westerse nie, bestempel hy laasgenoemde in die Afrikaanse 
poësie - wat Eugéne Marais, C. Louis Leipoldt, Toon van den Heever en N.P. van Wyk Louw insluit - as "die hoofrigting".

Sulke kategoriserings werk uiteraard vereenvoudigend, soos Opperman $(1959: 40,53)$ trouens self beklemtoon het. Dit word vandag as omstrede, weinig toepaslike stereotiperings ervaar (kyk Ohlhoff, 1999:75-76). Wat egter hier relevant is, is dat Opperman in hierdie opstel eintlik heel negatief oor Van den Heever se digwerk oordeel - in elk geval negatiewer as in sy proefskrif, wat in Junie 1952 voltooi en in 1953 deur Nasionale Boekhandel gepubliseer is onder die bekende titel Digters van Dertig (Steyn, 1998:661).

In laasgenoemde laat Opperman die kollig val op die vernuwing wat Dertig in die Afrikaanse poësie teweeggebring het, en wanneer hy dan 'n hoofstuk wy aan C.M. van den Heever, noem hy hom "Die eerste Dertiger". Hy beklemtoon onder meer die "nuwe eerbied vir die gevoelslewe en taal" (p. 127) wat spreek uit dele van Van den Heever se debuutbundel, Stemmingsure (1926), en "waarteenoor 'n mens besonder simpatiek staan in die jare van die dreunende vers, die vlammende maar leë impressionisme" (p. 131).

Sy bespreking van Van den Heever se volgende bundel, Die nuwe boord (1928), begin Opperman (s.j.:131) soos volg: "Die nuwe boord is 'n eienaardige bundel: dit bevat skaars één gedig wat 'n mens volkome bevredig, tog is dit 'n bundel letterlik vol pragtige brokstukkies. Verder het ons hier nog nie heeltemal die nuwe kuns nie, maar dit is reeds oral herkenbaar ...". As dit by Deining (1932) kom, is Opperman (s.j.:137138) al bereid om van "die eerste groot bundel van die Dertigers" te praat. "Triomfantelik breek die nuwe geluid deur in die Afrikaanse liriek," gaan hy voort.

Indertyd het die kritiek gepraat van 'n 'droogte' in ons poësie - al wat dit met die 'droogte' kon bedoel het, was die uitbly van nuwe name. Maar in die soeke na nuwe name is die nuwe by bekende jong digters nie voldoende gewaardeer nie.

Opperman (s.j.:144) wys spesifiek uit watter kenmerke van die Dertigerpoësie syns insiens in Deining hul beslag kry: die "verheerliking van die kunstenaar, die nuwe sintuiglikheid, beluistering van die eie sielelewe, groter ekspressiwiteit en 'n vryer en soepeler versbeweging".

Wanneer hy die "hoogtepunt" van Van den Heever se poësie-oeuvre, naamlik Aardse vlam (1938), bespreek - dié bundel het dus verskyn nadat die belangrike debute van W.E.G. Louw, N.P. van Wyk Louw, Uys Krige en Elisabeth Eybers gepubliseer is - beklemtoon Opperman (s.j.: 145) die omvang en invloed van Van den Heever se literêre werksaam- 
hede in die dertigerjare en konkludeer: "Eintlik was Van den Heever in hierdie jare die leidende digter, prosaskrywer en in 'n groot mate besieler en kritikus."

Opperman spreek in hierdie hoofstuk baie en ernstige kritiek uit oor die tekortkominge in Van den Heever se digkuns. Die indruk is egter onteenseglik dat hy hier, in die beklemtoning van die vernuwende elemente met betrekking tot die Afrikaanse poësie, op grond van literatuurbeskoulike oorwegings (wat Lotman, 1977:112-114, as 'n estetika van opposisie sou beskryf) 'n veel gunstiger oordeel oor Van den Heever se verskuns vel as in die opstel oor die vroulik-Oosterse ingesteldheid in sy werk. In laasgenoemde laat breër lewens- en wêreldbeskoulike oorwegings - met geslagtelike en kulturele stereotiperings - hulle eerder geld.

Sodanig gunstiger was die later oordeel van Opperman dat Van Wyk Louw in reaksie op Opperman se proefskrif geïnsinueer het dat Opperman die vernuwende elemente by Van den Heever oorskat het (Steyn, 1998:665). Hierop het Opperman geantwoord dat Van Wyk Louw weer die betekenis van Van den Heever ónderskat, naamlik in 'n poging om sy broer W.E.G. Louw as die eintlike eerste Dertiger te laat uitstaan (Steyn, 1998:689).

\section{Lewensbeskouingsgerigte waarderings van Van den Heever se verskuns}

Waardering van die lewensbeskoulike stratum van Van den Heever se werk, sonder om eintlik die estetiese vergestalting daarvan te ondersoek, word eerstens uitgespreek deur Abel Coetzee in C.M. van den Heever. Die wese van sy kuns (1936). Coetzee skryf oor veral die Calvinistiese basis van Van den Heever se kuns. In 'n tweede sodanige waardering, 'n huldeblyk by die afsterwe van Van den Heever, betreur D.F. Malherbe (1959:17) die verlies van sy behoudende religieus-beskoulike invloed, oftewel sy gedurige heenwysing "na ligtende einders".

lemand soos Grové (1949:27-35) is egter krities oor die gebrek aan besinning, die vaagheid van die religieuse gevoel in Van den Heever se werk. Hierdie kritikus se hoofsaaklik analitiese, teksgerigte literatuurbenadering (Kannemeyer, 1977:102), as gevolg waarvan hy "by uitstek (geboei word deur) die moderne geslote, heggeboude, kriptiese vers" (Wiehahn, 1965:138), 'n soort vers wat veral sedert die veertigerjare 'n prominente plek in die Afrikaanse poësie beklee het, spreek duidelik in sy oordele mee. Hy kom, wat die genoemde religieuse gevoel in Van den Heever se digkuns betref, tot die gevolgtrekking dat dit ook stilisties moet neerslaan. 
Hierdie onsekere en onbestemde lewensgevoel moet noodwendig sy styl nadelig beïnvloed; sy verse word dan ook so 'n trae, aanhoudende voortvloeiing van week-syige woordkombinasies en slap enjambemente waaraan stuwing en vaart ontbreek (Grové, 1949:28).

'n Besonder boeiende studie oor die verband tussen Van den Heever se lewensbeskouings en sy digstyl en verstegniek is die opstel "'n Vignet vir die digter C.M. van den Heever" deur T.T. Cloete (1970:14-18; oorspronklik gepubliseer in Standpunte, Feb./April 1957). Cloete skryf dat Van den Heever "die dinge van sy land onder 'n transendentale lig gesien het" (p. 14), 'n visie op die ondermaanse wêreld wat baie sterk verskil het van ander destydse Afrikaanse digters s'n. "Hy is die digter van 'n wêreld sonder ruimte en tyd, sonder vorm en kleur, die ewige wêreld" (p. 14).

Die dinge van hierdie aarde sien Van den Heever volgens Cloete (1970: 14) in hulle verganklikheid, en woorde soos sink, versmelt, stroom, gly of dryf, swewe, gaan verby, kwyn of verdwyn word gevolglik opvallend dikwels gebruik.

Hy sien ons wêreld die liefste in dié tye waarin die omtrekke van die dinge verlore gaan en vorme en afgerondhede vervaag, in sy geliefde seisoene, die herfs en winter. Of hy sien dit deur die newel, in die nag of skemer (...), in die skaduwee, deur die gryse reënatmosfeer of in die vervormende lugspieëling. (...) Hy noem by herhaling die likwiede aardse verskynsels: die wind wat hom in die ruimtes verloor, die veranderende, onvaste wolk, die water wat 'n bestemming anderkant die horison het, die spruit of rivier wat in die skemering versink, die kuil met sy skemerende dieptes, die stroom, die reën en veral die see. (...) Hy sien die mens in sy vergrysing en liefs as reisiger. (...) Ander kere weer het ons in sy gedigte te make met die gestorwe mens wat omgekom het in die oorlog, soos die Vlaamse soldate, die Boer of die Zoeloe-indoena, of die mens wat ondergegaan het in die tyd, soos die Germaan uit 'n verre eeu ...

Cloete (1970:15) wys voorts op hoe alles vir Van den Heever "wentel en dein" en dat hy die maatslag van die verbygaande wêreld ritmies noem. Hierdie likwiede, vervloeiende vind neerslag in die ritme van sy gedigte.

Sy ritme is nie 'n skeppende nie maar 'n passiewe, sonder weerstande. Die ritme van sy vers val saam met sy beeldspraak van die ritme. Dis 'n ritme wat uit die ewigheid die digter toeruis, sy vleuelslag laat hoor, dein, en slegs deur hom vloei. Hy vang daardie ritme maar op soos die gras of water waaroor die wind waai. Die passiwiteit is iets wesenliks in Van den Heever ... En hierdie passiwiteit het 'n sin: dis 'n oopgestel wees vir iets van buite, vir iets 
transendentaals, sodat die digter kan wees soos die see wat van buite, deur die verre planeet, die maan, beheers word, sodat hy kan wees soos die planete wat van die son, dus weer van buite, hulle lig ontvang, of soos die dryfsand wat beweeg word deur die waters wat daaroor gaan.

Die voëlbeeld, wat in verskeie gedaantes in Van den Heever se verskuns opduik, sou volgens Cloete as Van den Heever se vignet beskou kon word. Dié voëls is meestal swewende of verbygaande, of word getrek deur iets buite hulle, dikwels na die weste, "die windstreek van die dood en ondergang" toe, en word telkens teen 'n milieu van water en riet, wind en skemering, of bo die see en onder wolke waargeneem (Cloete, 1970: 15). In dié voëls "het Van den Heever se soms al te yle mymeringe, drome en hunkeringe vaste gedaante aangeneem" (Cloete, 1970:18).

Hierdie karakterisering van Van den Heever se digkuns deur Cloete, waarin die tematiese aspekte verhelderend en oortuigend met stilistiese en prosodiese elemente in verband gebring word, verteenwoordig waarskynlik die gunstigste motiveerbare beoordeling daarvan. Dit bied ook 'n deeglike verklaring van die unieke "eienheid" én (swakke) "eenselwigheid" van Van den Heever se digkuns, waarop nie net Cloete (1970:14) klem gelê het nie, maar ook - onder méér - Opperman (s.j.:131 e.v.), Van Heerden (1971:50) en Dekker (s.j.:199, 207).

As digter is Cloete glad nie so passief transendentaal gerig as Van den Heever nie; 'n teenstellende optimistiese, dinamiese prospektering na die Godsopenbaringe ín die aards-hiermaalse is eerder kenmerkend van sý poësie (vgl. Odendaal, 1997:104 e.v.). Naas Cloete se affiniteit vir die wesenlik Christelike lewensbeskoulike uitinge in Van den Heever se verse, is dit egter waarskynlik sy groeiende poësie-teoretiese oortuiging dat literatuur "vermenigvuldigde kommunikasie" behels - dit wil sê dat verstegniese en strukturele elemente nie net bloot bevestigend of ondersteunend van die woordbetekenis en poëtiese grondstof funksioneer nie, maar aktief daaraan meebou in 'n dinamiese diskursiewe proses (Johl, 1986:104-105) - wat Cloete 'n waarderende opstel soos dié oor C.M. van den Heever se digkuns kon laat skryf.

Dekades na dié opstel handhaaf Cloete in die huldigingsgedig "Hommage à CM van den Heever" uit die bundel Jukstaposisie (1982) steeds sy wesenlik positiewe oordeel oor die beskoulike en estetiese waarde van Van den Heever se gedigte - hierdie keer, blykens die titelonderskrif, met die kwalifisering: "al is dit vir min".

beste CM ek weet alte goed min mense lees

nog jou gedigte in die lig van die sekel- en volmaan 
van die literêre modes het die angswekkende mooi hees geskreeu van jou wildeganse inderdaad verlore gegaan

hier waar jy en jou eerder ontslape mooi indoena lank gelede eenmaal was hier wei nou snotneuslammerskape 'n hele kudde in die kortgras

\section{Verwantskappe met A. Roland Holst se digterskap}

"(E)k weet alte goed min mense lees/ nog jou gedigte ..." Dié woorde van Cloete laat 'n mens dink aan die lotgevalle van die digter A. Roland Holst binne die Nederlandse poësiewêreld. Weens die teksgerigtheid en die belangstelling in die meer verwikkelde teks van die literêre kritiek aldaar in die afgelope drie tot vier dekades, het die waardering sodanig afgeneem vir die meer enkelvoudige en direk belydende werk van dié man wat eens "de prins der dichters" in Nederland genoem is, dat hy tans eintlik net nog "als schrijver van levendige brieven in het literaire leven van het interbellum" gelees word (Van der Vegt, 2000:628).

Ek noem die geval A. Roland Holst met opset, want dié digter het 'n sterk invloed op Van den Heever se poësie gehad (Grové, 1949:32-33; Opperman, s.j.:140, 152). Dit is naamlik 'n volgende uitstaande verdienste van C.M. van den Heever se digterskap: dat hy 'n baanbrekende rol gespeel het om die heilsame inwerking van die Nederlandse digkuns rondom die wending tussen die negentiende en twintigste eeue (die Tagtigers, die Negentigers en die sogenaamde Generasie van Tien) op die Afrikaanse poësietoneel te bewerkstellig (Opperman, s.j.:124 e.v.; Dekker, s.j.:200 e.v.; Hattingh, 1959:67-69; Du Plooy, 1999:654). Geprikkel tot belangstelling in die Nederlandse letterkunde deur prof. A. Francken tydens sy studies aan die Grey-Universiteitskollege (soos die Vrystaatse Universiteit toe nog geheet het), het hy later 'n langerige studietydperk in Nederland en Vlaandere deurgebring (1928-1929) en daarna nog herhaalde besoeke aan veral Vlaandere afgelê. Op hierdie wyse het hy die neerslag van die genoemde Nederlandse en Vlaamse digtersgenerasies in die werk van vernaamlik die gebroeders W.E.G. en N.P. van Wyk Louw vooruitgeloop.

Veral A. Roland Holst is in hierdie verband te noem (vgl. Odendaal, 2001:130), want dié digter se werk is die naaste van al die Laelandse digters s'n verwant aan syne in gees en klank. 'n Soortgelyke werklikheidsvreemde gerigtheid of elisiese verlange word by Holst aangetref, hoewel dit in Holst se geval geen Christelik-religieuse onderbou gehad het nie, maar een uit die lers-Keltiese mitologie. Baie van die motiewe wat deur Cloete en die ander reeds genoemde kritici uitgewys is as 
kenmerkend van Van den Heever se digkuns, is ewe prominent in A. Roland Holst se oeuvre: sielsbelydenis; die ruisende wind, die deinende see en roepende meeue; wenteling en vervlaging; heimwee na 'n voortyd of 'n hiernamaalse, bo-wêreldlike tuiste ('n paradyslike eilandlewe) wat dikwels in die weste geleë is; skemering, verdonkering, vervreemding; 'n altyd kerende droefheid en lewens- en kultuurpessimisme. Die voortstromende vers en die stemmingsvolle woord- en klankgebruik is eweneens iets wat hulle gemeen het. (Vergelyk onder meer Opperman, s.j.:140, 152 en Jonckheere, 1988:309.)

\section{Die neerslag van die sensitivisme in Van den Heever se poësie}

'n Ander prominente invloed in Van den Heever se gedigte wat via sy belangstelling in die Nederlandse letterkunde op hom ingewerk het, en waarin hy veral W.E.G. Louw voorafgegaan het, is die impressionisme of sensitivisme (Opperman, s.j.:134, 139, 159; Dekker, s.j.:200, 204; Antonissen, s.j.:220; Van Heerden, 1971:51; Kannemeyer, 1988a:114).

Die impressionisme, as 'n ekstreme ontwikkeling van die strewe na realisme in die tweede helfte van die 19de eeu in Europa, het die subjektiwiteit van die werklikheidswaarneming deur die sintuie van die indiwidu gevier (Jonckheere, 1988:256-257). Die sensitivisme was 'n verdere ontwikkeling van die impressionistiese kunsstroming in die letterkunde, inderdaad 'n intensivering daarvan. Hiervan skryf Jonckheere (1988:277): "Hierdie soort woordkuns beweeg tussen uitdrukkings van uiterste sensitiwiteit en pogings om die onsegbare te sê, wat dit soms tot 'n voorloper van die eksperimentele kuns maak."

Lees 'n mens wat Jonckheere geskryf het saam met wat eers Dekker (1933) en toe Opperman (s.j.:320-321) en later Grové (1992:182-183) samevattend uit primêre Europese bronne oor die impressionisme/ sensitivisme sê, kan die volgende as uitstaande kenmerke van dié stroming in die poësie beskou word:

- 'n Weergawe van die fynste besonderhede van gewaarwording en waarneming (hewige sinlike en psigiese gewaarwordings) en 'n poging om die onsegbare te sê. Die waarneming lei volgens sensitivistiese teoretici tot 'n "impressie" deur die objek op die subjek, wat weer 'n "sensasie" en ten slotte 'n "ekstase" by die subjek tot gevolg het. Dit verteenwoordig dus 'n ewolusie van loutere waarneming tot geestesverrukking én tegelykertyd 'n poging om die unio mystica (die mistieke eenwording) van subjek en objek te bereik. 
- Die sensitivistiese digkuns word gekenmerk deur verfynde en verrassende beeldvondste.

- Sintuiglikheid speel 'n belangrike rol in hierdie poësie.

- Subtiele versbeweging (ritme, klankskildering, ensovoorts) is kenmerkend en daar is 'n strewe in die sensitivistiese poësie om suiwer musiek te wees.

- Daar word gestreef na trefsekere woordkeuse, dikwels met 'n voorkeur vir die mooi woord (met die gevare van "estetisisme" wat dit inhou).

- Waar die veranderlike lig die kreatiewe beginsel van die skildermedium (verf) in die impressionisme was, was die medium vir die sensitivistiese digter die beweeglike werkwoord en die stemmingsryke adjektief. Om, soos die skilder, sy unieke indrukke van die werklikheid fyn en subtiel te kan weergee, wend die sensitivistiese digter hom "tot die komplekse en gevolglik neologistiese taalgebruik (woordskeppings en samestellings) en nie-rasionele sinsbou, eweas tot 'n ontbreek van duidelike omlynings in beeldspraak of beskrywings. Die vaagheid van impressionistiese literêre werke moet 'n mens parallel stel met die diffuusheid en die poging tot ontmaterialisering wat so dikwels in impressionistiese skilderye voorkom" (Jonckheere, 1988:257).

- Gevoeligheid vir "stemmings"-dinge soos lig, kleur, trae bewegings, laag swewende wolke, reën, nag, see en eensaamheid kom tipies in sensitivistiese poësie voor.

Hoewel 'n mens nie Van Heerden kan uitmaak as 'n volbloedsensitivis soortgelyk aan die Nederlander Herman Gorter wat hy bewonder het nie, het heelwat van die eienskappe van die sensitivisme tog neerslag gevind in sy gedigte, waaronder welbekendes soos "Die konsertina in die nag", "Voëls in die skemering", "O koele water van die spruit", "O verre wydtes" en "Die vertrekkende wildeganse" tel. "Voëls in die skemering" (Deining, 1932 ) is ' $n$ goeie voorbeeld om sodanige neerslag in meer besonderhede aan te toon.

\section{Voëls in die skemering}

Voëlgeklepper in die skemer

oor buigende riet,

en soos vlae wit sneeu

uit die ruimte, die hemel,

daal hulle neer,

daal soos 'n droom. 


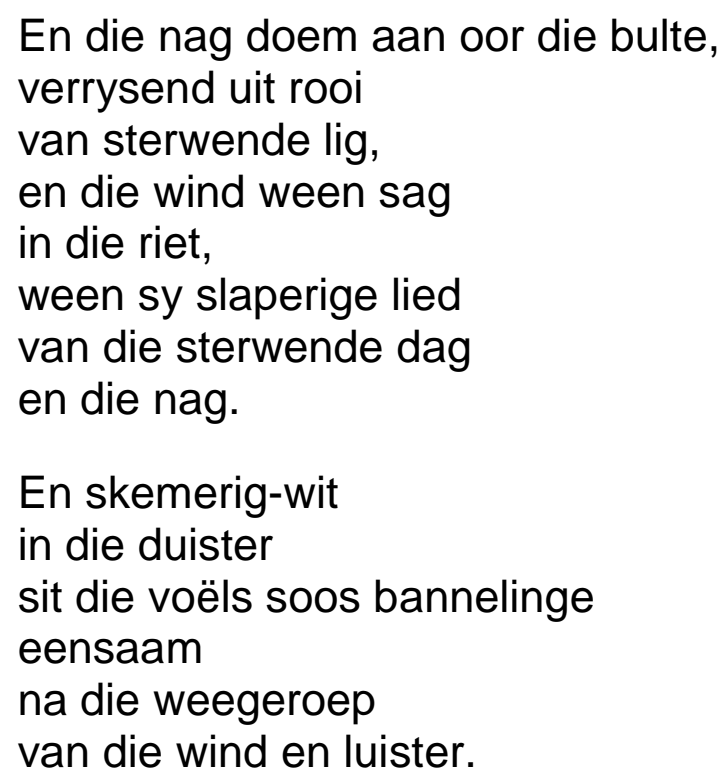

Daar is iets van die kenmerkende stappe van waarneming tot impressie tot sensasie tot ekstase, soos deur die sensitivistiese teoretici onderskei. Die waarneming van die vlerkgeklepper van die aankomende voëls in die skemering lei tot die indruk van 'n dalende droom - vergelyk met "vlae wit sneeu" - by die nie-gespesifiseerde spreker (daar is nie van 'n "ek" sprake nie).

Die hoofsaaklik personifiërende uitdrukkings "doem aan", "sterwende lig/dag" en "die wind ween ... sy slaperige lied" in strofe 2 verklap die subjek se sensasie van die alles oorweldigende sterflikheid en die belewing van droefheid wat daarmee gepaardgaan. In strofe drie groei dié sensasie uit tot 'n ekstatiese meelewing met die lot van die voëls. Dit is juis belangrik dat die spreker nooit geïdentifiseer word nie, want woorde soos "bannelinge", "eensaam" en "weegeroep", met hulle menslike gevoelswaardes, wys dat die voëls eintlik sinnebeeldig van die mens is - mens en voëls verkeer in mistieke eenheid.

Van den Heever is nie bekend vir sy skerp sintuiglikheid (die kleurwaarnemings is byvoorbeeld beperk tot rooi, wit en "duister") of vir sy verfynde en verrassende beeldvondste nie. Daar was trouens baie kritiek op die "eenselwige en dikwels ondeurdagte beeldspraak" (Du Plooy, 1999:658) in sy poësie-oeuvre. Ook hier is die twee beelde wat naas die genoemde personifikasies voorkom - die sneeu-beeld vir die dalende en die banneling-beeld vir die luisterende voëls - nie besonder verrassend of selfs treffend nie.

Sterk teenwoordig is egter sensitivistiese stemmingsdinge en -woorde: skemering; die nag wat aandoem; wind wat deur die riete "ween"; die voëls wat traag soos sneeuvlae of soos "n droom" daal; eensaamheid 
en bannelingskap. Adjektiewe soos "buigende", "sterwende" en "slaperige" dra tot dié stemmingsvolheid by.

Van den Heever gaan ook nie in dié gedig so ver soos Europese sensitiviste wat neologistiese taalgebruik en nie-rasionele sinsbou aanwend om die werklikheid in fyn en subtiele besonderhede te evokeer nie. Ritmies en klankmatig skuil daar egter heelwat subtiliteit in die gedig. Grové (1977:69) noem byvoorbeeld dat die telkens terugkerende langgerekte e-klank - in die bepaalde sfeer van woordkeuses soos "skemer", "sneeu", "hemel", "neer", "ween", "skemerig" "eensaam" en "weegeroep" - uiteindelik klanksimbolies werk en " $n$ gevoel van doodsangs wakker roep". Die sterk enjambemente in die eerste en derde reëls van die eerste strofe, tesame met herhalingseffekte in die daaropvolgende reëls ("uit die ruimte, die hemel,/ daal hulle neer,/ daal soos 'n droom"), is funksioneel suggererend van die beweging waarvan daar sprake is.

In reël 1 van strofe 2 werk die ploffers en die donker vokale in "doem" en "bulte" versterkend in op die woordbetekenisse. Verder is die herhaling van die $w$ - en $s$-klanke in hierdie strofe en die slotstrofe funksioneel om die sagte geween van die wind in die riete waarna die voëls sit en luister te suggereer.

Naas sekere vroeër werk van die Dertigers (Jonckheere, 1988:281), waaronder veral Van den Heever en W.E.G. Louw s'n tel, bestaan daar weinig gedigte in Afrikaans wat as sensitivisties van aard bestempel kan word. "Voëls in die skemering" verteenwoordig die mees verfynde voorbeelde hiervan. Dit sal 'n groot literêr-historiese verlies vir Afrikaans wees as Van den Heever se baanbrekende werk in hierdie verband in die vergetelheid raak.

\section{Redes vir die marginalisering van Van den Heever se digterskap}

Die feit dat te veel van Van den Heever se verse weens die stilistiese en verstegniese onsuiwerhede, die onheldere stemmingsvolheid en die eentonigheid daarvan as digterlike werke tekortskiet, het natuurlik in die eerste plek bygedra daartoe dat hy, spesifiek sedert die veertigerjare, 'n steeds geringer digterlike aansien kon geniet.

In die tweede plek het twintigste-eeuse verskuiwings in heersende literatuuropvattings, wat ook in die Afrikaanse literêre veld hul invloed laat geld het, belangstelling in die soort digkuns wat Van den Heever geskryf het, steeds laat taan. 
'n Nuttige model om in hierdie verband te gebruik, is dié van M.H. Abrams (1953), soos kortliks saamgevat deur Van Rees en Dorleijn (1994:100). Op grond van vier verskillende verhoudings word vier verskillende soorte literatuuropvattings onderskei: dié waarin die verhouding teks-werklikheid oorheers (die mimetiese literatuuropvatting); dié waarin die verhouding teks-samelewing primeer (die pragmatiese literatuuropvatting); dié waarin die verhouding teks-digter die belangrikste is (die ekspressiewe literatuuropvatting); en dié waarin die verhouding teks-sigself oorheers (die outonomistiese literatuuropvatting).

Gaan 'n mens die ontwikkelingsgang van die Afrikaanse literêre kritiek in die twintigste eeu sedert die tyd dat Van den Heever as digter gedebuteer het (Stemmingsure, 1926) na soos dit onder meer deur Wiehahn (1965), Kannemeyer (1977:97-105 en 1988b:33-35) en Johl (1986) bespreek is, bemerk 'n mens breedweg, sonder absolute skeidslyne in die tyd, dat bostaande literatuurbeskoulike onderskeidinge soos volg in die Afrikaanse literêre veld oorheers:

- twintiger- en dertigerjare - die ekspressiewe (psigologistiese) literatuuropvatting;

- vanaf ongeveer 1935 tot ongeveer 1975 - die outonomistiese literatuuropvatting;

- vanaf die sewentigerjare - die pragmatiese en mimetiese literatuuropvattings, min of meer in tandem.

Op enkele gedigte na - waaronder "Die gevalle Zoeloe-indoena", "Die ewige kind", "Afrika", "Die gepensioeneerde" en "Agter tralies" - het Van den Heever nooit verby die stemmingsvolle belydenisvers beweeg nie. Vanaf ongeveer 1935 het die Afrikaanse literêre kritiek egter in fases al suiwerder teksgerig geraak (totdat dié benadering vanaf ongeveer 1975 toenemend bevraagteken is - vergelyk Johl, 1986:35), met 'n gevolglike voorkeur vir die beeldende, verwikkelde en gelaagde gedig (Kannemeyer, 1988b:34) en geen groot erg aan enkelvoudige belydenispoësie soos dié van Van den Heever nie. Algaande, soos A. Roland Holst in Nederland, het Van den Heever as gevolg van dusdanige literatuurbeskoulike verskuiwings tot die marge van die Afrikaanse poësiekanon geraak.

Dit is eintlik jammer dat hy nie meer maatskaplik betrokke en beeldende gedigte geskryf het nie, want sulke verse is dikwels juis aangeprys deur kommentatore wat andersins heel krities teenoor sy verskuns was (byvoorbeeld Dekker, s.j.:199; Van Rensburg, 1971:131, Eybers, 1978: 44 en Van Heerden, 1971:52). Die skryf van dramaties-beeldende en maatskaplik betrokke verse het waarskynlik nie gestrook met sy 
sensitiewe, essensieel onmaatskaplike digterspersoonlikheid nie. D.F. Malherbe (1959:14) was van mening dat dié aard van sy karakter die rede was waarom hy nie dramatiese werk geskryf het nie. "Nie fors in beelding nie, was hy begaaf met 'n fyn oog om die vlietende gebaar van die oomblik vas te gryp in menslike verhoudinge of in natuurgegewe."

'n Ander siening in hierdie verband kom van F.I.J. van Rensburg (1971:131):

'n Mens wonder partymaal of die feit dat Van den Heever so baie prosa geskryf het, nie die oorsaak daarvan was dat so min van sy poësie die tekens dra dat dit spesifiek as poësie 'ontvang en gebore is' nie. Daar is 'n sekere gemis aan geslotenheid, aan struktuur, wat nie verband hou met die sagte, peinsende, voortlopende mymering wat die inhoud daarvan is nie. (...) Dis of die gedigkristal dit moeilik regkry om saam te trek uit 'n grys moederloog wat so gestadig aan die beweeg gehou word.

'n Groter getal polities-maatskaplik betrokke gedigte uit sy pen sou waarskynlik ook meegewerk het om meer waardering vir sy digterskap in die tydperk na 1975 te verseker. Soos voorheen aangedui, het die outonomistiese benadering tot letterkunde in die afgelope dekades toenemend die oorheersende posisie moes afstaan aan opvattings waarby 'n sterker aksent geplaas is op sowel die lesersrespons as "op het functioneren van het literaire werk binnen verschillende contexten" (Goedegebuure \& Heijnders, 1998:16). Die aandrang op betrokke Afrikaanse literatuur in veral die polities onstuimige sewentiger- en tagtigerjare en die sterk post-koloniale tendense in Afrikaanse literatuur van die afgelope dekade en meer is opvallende uitinge hiervan.

Die beste aanduider van 'n digter se statuur sal die hoeveelheid gedigte wees waarvoor hy onthou word. In Van den Heever se geval is dit vir 'n relatief klein aantal gedigte uit sy oeuvre. Slegs 25 uit die meer as 400 (sowat 6\%) van sy oorspronklik gebundelde gedigte is in totaal in die volgende bekende bloemlesings opgeneem: D.J. Opperman se 1983weergawe van Groot verseboek (negende uitgawe), André P. Brink se samestelling van Groot verseboek 2000, Gerrit Komrij se Die Afrikaanse poësie in 'n duisend en enkele gedigte uit 1999, asook Junior verseboek (1981) en Senior verseboek (1983) soos saamgestel deur Opperman.

In tien tematiese Afrikaanse bloemlesings wat tussen 1986 en 1999 verskyn het en waarin potensieel van Van den Heever se gedigte 
opgeneem kon wees ${ }^{1}$, is net vier gedigte van Van den Heever opgeneem: "Ek vrees nie meer die dood" in Die braambos brand. 'n Keur van godsdienstige gedigte (Nienaber \& Nienaber-Luitingh, 1987), "Die ewige kind" in Bloeityd. Verse oor kinders (Johl \& Cilliers, 1993) en "Musiek" en "Die konsertina in die nag" in Liggaamlose taal. Gedigte oor die musiek (Human, 1996).

As sentrale dokument wat die Afrikaanse poësiekanon betref (vergelyk onder meer Ohlhoff, 1995 en Van Coller, 1999), spreek die genoemde verskillende uitgawes van Groot verseboek 'n gewigtige woord in hierdie verband. Waar Opperman nog elf gedigte of gedigfragmente van Van den Heever opgeneem het, laat Brink dit dramaties krimp tot vyf: "Die konsertina in die nag", "Voëls in die skemering", "Die gevalle Zoeloeindoena", "Die vertrekkende wildeganse" en "Die ewige kind".

Dalk sal toekomstige literatuurbeskoulike verskuiwings tot gevolg hê dat meer gedigte van Van den Heever as bogenoemde handjievol aan die vergetelheid ontsnap. Intussen lyk dit of C.M. van den Heever as digter, aan die hand van dié enkele gedigte van hoogstaande gehalte, eintlik net vir sy baanbrekende rol in die vernuwing van Dertig onthou word. Terwyl die Nederlandse letterkunde steeds aan sekere Suid-Afrikaanse universiteiteite onderrig word (vgl. Odendaal, 2001:128-130), is daar ook die moontlikheid dat sommige van sy verse steeds vergelykenderwys met byvoorbeeld die sensitivistiese werk van Herman Gorter of die simbolistiese poësie van A. Roland Holst bestudeer sal word, en dat sy bemiddelende rol om Nederlandse poësiestrominge uit die begin van die twintigste eeu hulle uitwerkinge in die Afrikaanse poësie te laat hê, sodoende gedenk sal word.

1 Die mooiste Afrikaanse liefdesgedigte, eerste uitgawe 1986, met "n nuwe groter keur" in die tweede uitgawe van 1992, asook 'n derde, uitgebreide uitgawe in 2001, saamgestel deur Fanie Olivier; Die braambos brand. 'n Keur van godsdienstige gedigte (1987), saamgestel deur die egpaar C.J.M. Nienaber \& M. Nienaber-Luitingh; Speelse verse (1988), saamgestel deur Daniel Hugo; Miskien sal ek die wingerd prys. Ryme en gedigte oor wyn en sterk drank (1989), uitgesoek deur Daniel Hugo \& Etienne van Heerden; Groen. Gedigte oor die omgewing (1990), saamgestel deur Johann Lodewyk Marais; Bloeityd. Verse oor kinders (1993), bymekaargebring deur Johann Johl \& Rika Cilliers; Jubilate! Loofgedigte in Afrikaans (1995), gekies deur F.I.J. van Rensburg; Liggaamlose taal. Gedigte oor die musiek (1996), uitgesoek deur Koos Human; Ons klein en silwerige planeet. Afrikaanse, Nederlandse en Vlaamse gedigte oor die omgewing (1997), saamgestel en ingelei deur Johann Lodewyk Marais en Ad Zuiderent; en Die dye trek die dye aan. Verse oor lyflike liefde (1998), byeengebring deur Johann de Lange en Antjie Krog. 


\section{Bibliografie}

Abrams, M.H. 1953. The mirror and the lamp: romantic theory and the critical tradition. New York : Oxford University Press.

Antonissen, R. s.j. Die Afrikaanse letterkunde van aanvang tot hede. 3de, hersiene uitgawe, 2de druk. Kaapstad : Nasou.

Brink, A.P. (samest.) 2000. Groot verseboek 2000. Kaapstad : Tafelberg.

Cloete, T.T. 1970. Kaneel. Studies oor die poësie, prosa en die kunsteorie. Kaapstad : Nasionale Boekhandel.

Cloete, T.T. 1982. Jukstaposisie. Kaapstad : Tafelberg.

Coetzee, Abel. 1936. C.M. van den Heever. Die wese van sy kuns. Pretoria : Van Schaik.

Coetzee, Ampie. 2000. 'n Hele os vir 'n ou broodmes. Grond en die plaasnarratief sedert 1595. Pretoria/Kaapstad: Van Schaik/Human \& Rousseau.

Dekker, G. 1933. Die impressionisme in die Nederlandse letterkunde. Pretoria : De Bussy.

Dekker, G. 1959. Christiaan Maurits van den Heever. (Oorspronklik in Koers gepubliseer, Oktober 1957.) In: Nienaber, P.J. (samest.) Gedenkboek C.M. van den Heever (1902-1957). Johannesburg : Afrikaanse Pers-boekhandel. p. 1922.

Dekker, G. s.j. Afrikaanse literatuurgeskiedenis. 12de druk, bygewerk tot 1966. Kaapstad : Nasou.

De Lange, J. \& Krog, A. (samests.) 1998. Die dye trek die dye aan. Verse oor lyflike liefde. Kaapstad : Human \& Rousseau/Tafelberg.

Du Plooy, H. 1999. (Profiel van) C.M. van den Heever. In: Van Coller, H.P. (red.) Perspektief en profiel. 'n Afrikaanse literatuurgeskiedenis, deel 2. Pretoria : Van Schaik Akademies. p. 653-664.

Eybers, E. 1978. Voetpad van verkenning. Kritiese opstelle. (Ingelei deur J.C. Kannemeyer.) Kaapstad/Pretoria : Human \& Rousseau.

Goedegebuure, Jaap \& Heijnders, Odile. 1998. Literatuurwetenschap in Nederland. Een vakgeschiedenis. Amsterdam : Amsterdam University Press.

Grové, A.P. 1949. Die duister digter. Opstelle oor die moderne Afrikaanse liriek. Pietermaritzburg/Durban : Universiteitspers.

Grové, A.P. 1977. Woord en wonder. Inleidende studie oor die tegniek van die poësie. 4de uitgawe. Elsiesrivier : Nasou.

Grové, A.P. 1992. Impressionisme. In: Cloete, T.T. (red.) Literêre terme en teorieë. Pretoria : HAUM-literêr. p. 182-183.

Hattingh, S.C. 1959. Mens en kunstenaar. (Oorspronklik in Tydskrif vir Letterkunde gepubliseer, Sept. 1957.) In: Nienaber, P.J. (samest.) Gedenkboek C.M. van den Heever (1902-1957). Johannesburg : Afrikaanse Pers-Boekhandel. p. 6583.

Hugo, D. (samest.) 1988. Speelse verse. Kaapstad : Tafelberg.

Hugo, D. \& Van Heerden, E. (samests.) 1989. Miskien sal ek die wingerd prys. Ryme en gedigte oor wyn en sterk drank. Kaapstad : Tafelberg.

Human, K. (samest.) 1996. Liggaamlose taal. Gedigte oor die musiek. Kaapstad : Human \& Rousseau.

Johl, J. \& Cilliers, R. (samests.) 1993. Bloeityd. Verse oor kinders. Kaapstad : Tafelberg.

Johl, R. 1986. Kritiek in krisis: Vryheid vir die teks. Durban : Butterworth. 
Jonckheere, W.F. 1988. Periode van vernuwing en idealisme. In: Van der Elst, J., Ohlhoff, H. \& Schutte, H.J. (reds.) Momente in die Nederlandse letterkunde. Pretoria/Kaapstad : Academica. p. 239-318.

Kannemeyer, J.C. 1977. Bestekopname van die Afrikaanse literêre kritiek. In: Konfrontasies. Letterkundige opstelle en kritiek 1961-1975. Pretoria : Academica. p. 97-105.

Kannemeyer, J.C. 1988a. Die Afrikaanse literatuur 1652-1987. Pretoria/ Kaapstad : Academica.

Kannemeyer, J.C. 1988b. Uys Krige: Die buitestaander onder die Dertigers. In: Kannemeyer, J.C. (samest.) Die veelsydige Krige. Vyf studies oor die skrywer en die mens. Kaapstad/Pretoria : Human \& Rousseau. p. 32-46.

Kannemeyer, J.C. 1998. Verse vir die vraestel. 'n Poësiegids. Kaapstad : Tafelberg.

Komrij, G. (samest.) 1999. Die Afrikaanse poësie in 'n duisend en enkele gedigte. Amsterdam : Bakker.

Lotman, J. 1977. Teksttypologie en de typologie van de tekst-externe verbanden. In: Bronzwaer, W.J.M., Fokkema, D.W. \& Kunne-lbsch, E. (reds.) Tekstboek algemene literatuurwetenschap. (Vertaal deur $\mathrm{H}$. de Zwaan.) Baarn : Basisboeken Ambo. p. 107-120.

Malherbe, D.F. 1959. lets oor C.M. van den Heever en sy werk. (Oorspronklik in Tydskrif vir Letterkunde gepubliseer, Sept. 1957.) In: Nienaber, P.J. (samest.) Gedenkboek C.M. van den Heever (1902-1957). Johannesburg : Afrikaanse Pers-Boekhandel. p. 13-18.

Marais, J.L. (samest.) 1990. Groen. Gedigte oor die omgewing. Pretoria : HAUMliterêr.

Marais, J.L. \& Zuiderent, A. (samests.) 1997. Ons klein en silwerige planeet. Afrikaanse, Nederlandse en Vlaamse gedigte oor die omgewing. Pretoria : Van Schaik.

Nienaber, C.J.M. \& Nienaber-Luitingh, M. (samests.) 1987. Die braambos brand. 'n Keur van godsdienstige gedigte. Kaapstad : Tafelberg.

Odendaal, B.J. 1997. Retoriese strategieë in die poësie van T.T. Cloete. Bloemfontein : Universiteit van die Oranje-Vrystaat. (Ph.D.-proefskrif.)

Odendaal, B.J. 2001. A. Roland Holst se nalatenskap in die Afrikaanse poësie: Terugblik by die verskyning van 'n biografie. Stilet, 13(3):123-146, Sept.

Ohlhoff, H. 1995. Kanon en instansies - 'n Afrikaanse perspektief. Tydskrif vir Letterkunde, 33(2):39-46, Mei.

Ohlhoff, H. 1999. Perspektief op die Afrikaanse poësie: die poësie van voor 1900 tot 1960. In: Van Coller, H.P. (red.) Perspektief en profiel, 'n Afrikaanse literatuurgeskiedenis, deel 2. Pretoria : Van Schaik Akademies. p. 21-243.

Olivier, F. (samest.) 1986. Die mooiste Afrikaanse liefdesgedigte. Kaapstad : Human \& Rousseau.

Olivier, F. (samest.) 1992. Die mooiste Afrikaanse liefdesgedigte. 'n Groter keur. Kaapstad : Human \& Rousseau.

Olivier, F. (samest.) 2001. Die mooiste Afrikaanse liefdesgedigte. 'n Nuwe keur. Kaapstad : Human \& Rousseau.

Opperman, D.J. s.j. Digters van Dertig. 3de druk. Kaapstad : Nasou.

Opperman, D.J. 1959. Wiggelstok. Kaapstad : Nasionale Boekhandel.

Opperman, D.J. 1981. Junior verseboek. 6de uitgawe. Kaapstad : Tafelberg.

Opperman, D.J. 1983. Senior verseboek. 5de uitgawe. Kaapstad : Tafelberg.

Opperman, D.J. 1983. Groot verseboek. 9de uitgawe. Kaapstad : Tafelberg.

Steyn, J.C. 1998. Van Wyk Louw. 'n Lewensverhaal. Kaapstad : Tafelberg. 
Van Coller, H.P. 1987. Laat vrugte behandel deur prof. H.P. van Coller. ReuseBlokboek 20. Pretoria/Kaapstad : Academica.

Van Coller, H.P. 1999. Die bloemleser as kanoniseerder. Sewende D.J. Oppermangedenklesing. Stellenbosch : Universiteit van Stellenbosch.

Van der Vegt, J. 2000. A. Roland Holst. Biografie. Baarn : Uitgeverij de Prom.

Van Heerden. E. 1971 (geskryf in 1959). C.M. van den Heever. In: Rekenskap. Letterkundige opstelle. 2de druk. Kaapstad : Tafelberg. p. 50-56.

Van Rees, C.J \& Dorleijn, G.J. 1994. Literatuuropvattingen in het literaire veld: over de integratie van twee benaderingen. Spektator, 23:91-114.

Van Rensburg, F.I.J. 1971. Die smal baan. Aspekte en figure uit die ontwikkelingsgang van die Afrikaanse letterkunde. Tweede om- en bygewerkte uitgawe. Kaapstad : Tafelberg.

Van Rensburg, F.I.J. (samest.) 1995. Jubilate! Loofgedigte in Afrikaans. Kaapstad : Tafelberg.

Wiehahn, R. 1965. Die Afrikaanse poësiekritiek. 'n Histories-teoretiese beskouing. Kaapstad/Pretoria : Academica.

\section{Kernbegrippe:}

waardepeilings: C.M. van den Heever se poësie oorgangsfiguur in Dertiger-vernuwing

bekendstelling: Nederlandse poësie-elemente - wending 19de eeu simbolisme in die letterkunde verskuiwings: heersende literatuuropvattings

\section{Key concepts:}

evaluations: C.M. van den Heever's poetry

transitional figure in Afrikaans poetry renewal in the 1930s introduction of elements of Dutch poetry - turn of 19th century shifts: dominant literary approaches

symbolism in literature 